\title{
地域的集中総合指標からみた東京への集中
}

\author{
千 歳 壽 一*
}

\section{A Study on Concentration Index and Degree of Concentration in Tokyo}

\author{
Juichi Chitose*
}

\section{I.はじめに}

「東京への一極集中」,「諸機能の一極集中」,「情 報・サービス業売上の $50 \%$, 外国銀行の約70\%が 東京へ集中」等々, 東京への集中が, 様々な紙面 を賑わしたことは記憶に新しい。東京への一極集 中が，今までにも度々問題になったが，今回のよ うに大きな社会的な問題として取り上げられたの は初めてといってよい。

そのため, 地域的な集中について基本的な事項 が研究されないまま, 恣意的な説が次々と出され ている。実証性に乏しい推測をもとに政策形成を 目指寸議論が進められるのは, いささか問題であ る。しかし、これを契機に, 集中の研究が本格的 に行われ，政策に反映されれば，結果的に地域開 発や都市整備の前進につながって行くことになる であろう。

本研究は, 地域的集中研究の一端を担おうとす る意図の下に，地域的集中の総合的な尺度による 計測方法の開発を試みたものである。東京への集 中がどの程度であるかが明らかになれば，地域的 集中研究の基礎資料の充実に寄与寸るとともに, 政策検討に有用な情報を提供することになる。 地域的集中を計測する尺度も定まっていない現 状では, 地域的集中を明確に把握することはでき ない。しかし逆に，ある程度地域的集中の実態が 分かっていないと, 適切な尺度を作ることはむつう かしい。どちらかから出発して, 一段階ゔ改良
していくことが必要である。

\section{II. 地域的集中の考え方と計測方法}

1. 地域的集中の概念

地域的な集中, 略して「集中」という言葉につ いて，合意された明確な 定義はまだできていな い。ここでは「集中」を,「集積」がより進むこと とする。まず「集積」とは,「人口等が，一定の 地域にある程度まとまって定着している状況」で あるとし11，狭義の「集中」とは，「人口等の集積 の度合いのより低い複数の地域から, 集積の度合 いの高い特定の地域一移動し, より高度に集積す ること」とし，広義の「集中」は，上記に「明ら かに, 他の地域より高度な集積に達したこと」を 加えたものとする。

人口が他の地域から東京へ転入したり, 企業が 地方から東京へ移動したりすることが集中であっ て, 文字通りフローの概念である。それに対して 集積は集中の結果であって, いわばストックの概 念である。広義の集中は，ストック概念である集 積の特別な状態を含めたものである。また，集中 は, 全体地域対部分地域, あるいは上位の地域対 下位の地域という構造的な概念である。そして, 移動とそれによる変化という動的な 概念でもあ る。集中した若年人口によって，やがて人口の自 然増が高まり, 結果的に人口が増加するような状 況を,「集中による人口増」と考えるのは適切で はない。自己増殖によって増大する場合は, 集積

* 東京都職員研修所調查研究室

Research Office, In-Service Training Institute, Tokyo Metropolitan Government 
の高度化であり，それが集中の状態を呈している ことである。

集中による都市の変貌に関して，「都市化」と いう概念があり, 地理学, 経済学, 社会学などの 研究の対象になっている2)。人口の集中について も, 人口の移動として, 地理学や経済学で研究さ れている3)。集中の著しい都市と他の都市との関 係は, 主に地理学において都市システムとして研 究が進められている4。

集中の調查・研究が, 従来からの都市化・移 動・都市システムの研究の延長上にあるのか, 別 なものか, 現時点で確定的な結論を出すのは時期 尚早である。しかし, 都市化・移動・都市システ ムとの間に次のような 視点の 差があると思われ る。

都市化の研究が個々の地域を対象にするのに対 して, 集中は, 全体と部分の構造的な把握を目指 す。地域間の関連を重視し，広い地域から一つの 都市への集中とともに，都市内の部分における集 中をも対象にする。このことは，単に地域間の移 動だけでなく, 移動先の地域の変化を同時に把握 することを意味する。人口や企業等の都市への集 中によって，機能と環境に変化が生じ，それが機 能を十分に発揮するための都市環境整備を呼起こ し, 次の集中の条件を変化させる。集中の調査 · 研究は, 都市化, 地域間移動, 都市間の関連を総 合的・動的に取り扱うことを，目的とするのであ る。

2. 集中調查・研究の目的と対象

人口の集中，あるいは企業の集中のように，集 中する主体は数多くある。都市への集中はなにの 集中をもって捉えたらよいのか, 未だ明らかでな い。都市は, 多数の要素によって構成されている ため，集中の主体として取上げうる要素は数多く ある。従って，なんのために集中を調べるのかと いう調查・研究の目的に応じて, 調査対象を絞っ ていくことになる。

実務的視点に立った場合, 集中を調査・研究す る目的の一つは, 地価高腾や過密化など, 他の地 域からの集中によって生じる問題に対応するため の資料を得ることである。集中を調査・研究する ことによって, 都市整備のためのより基本的な情
報を得ることができる。

もう一つの目的は，集中の進んだ都市や地方が 他の地域に及ぼす影響を知ることである。予想さ れるゼロサム社会においては，地域間競争が激化 し一地域への集中が他の地域の衰退を招く恐れが 強くなるため，集中を制御管理することが一層重 要になり，集中のメカニズムを知る必要性は更に 高まると推測される。

既に述べたように，集中の本格的研究は日が浅 く，未知の部分が多いため，どのデータが目的達 成に必要なのか正確にはわかっていない。収集可 能なデータによる試行錯誤を経験しながら，徐々 に明確化していくことが期待されている。

本研究は, 複数の要素を用いて, 集中状況を測 定する総合的な尺度を考案することを目的にし， それによって，東京や東京圈各県の集中状況を量 的に把握しようとするものである。

3. 対象地域

東京集中としばしばいわれるが，外国金融機関 や郵便物引受数など，明らかに集中しているもの を除いて，統計上，東京都には，人口や事務所従 業者のように，対全国シェアだけでなく絶対数を 下げている要素も少なくない。これはドーナッッ 現象によるものとして知られており，東京都で減 少した以上に，東京都に隣接する近県で増加をみ ている。東京都, 埼玉県, 千葉県, 神奈川県の 1 都 3 県からなる東京圏で, 確実に集積が進んでい るのである。

このように，集中を論ずるためには，基礎とな る地域を明確にしておくことが必要である。行政 上の地域としては, 都道府県と市町村が基本にな っているが，都市化の進展によって実質的な都市 の区域は，行政区域を越えて拡がっている。

南関東に位置する東京都, 埼玉県, 千葉紧, 神 奈川県の 1 都 3 県は, それぞれの主要な部分が連 坦した市街地をなしており，通勤圏としても日常 の生活圈としても密接に結ばれているため, 東京 圏と呼ばれている。同圏は，統計資料の整備状況 からも，東京への一極集中を検討するための最適 な地域の一つと考えられている。

東京都は，東京圈の中心であるが，同時に都道 府県の一つでもある。一般に東京への集中は，首 
都東京の問題として論じられることが多く, 東京 都の問題としての側面はあまり考虑されていない ことが多かった。地方自治体としての東京都庁が 集中対応策を進める場合, 当然, 東京都の行政区 域を，一つの対象地域にする。更に，集中のこれ までの実態から，東京都区部，千代田・中央・港 の3 区からなる都心三区，それに副都心を擁する 新宿・渋谷・豊島を加えた中心部 6 区などが，調 查・検討の対象地域となる。

\section{III. 既存の集中の表示方法による集中 状況の把握}

集中を表示するための指標は，既にいくつか考 案されている。それらは，個々の地域の状態をみ るための指標と，それぞれ個々の地域を全部含め た全体の 集中状況を 知るための 指標に大別でき る。

\section{1. 個別地域の集中指標}

(i) 構成比

構成比は, この場合正確には地域別構成比であ るが，対象としている地域で発生した事象の全地 域に対して占める割合を示す単純な尺度である。 東京の一極集中を述べる際必ずといってよいほど 出てくるのが，日本の情報産業の $70 \%$ 東京都に 集中しているというょうな文で，構成比の大きさ で集中を表現しようとしている。

(ii) 構成比密度

地域に関する数値は，面積に関する数值という ことができる。東京都の 人口が 1200 万であって も, 行政区域面積が充分広ければ過密の問題は起 こらないはずである。全国の僅か $0.6 \%$ の土地に， $10 \%$ に近い人口が集中しているので，様々な問題 が起こっているのである。

構成比を事象そのものについてだけではなく， 面積の構成比と比較すること，すなわち，事象の 構成比を面積の構成比で割り，いわば構成比の土 地に対する密度を求めることによって，集中の実 態をより明確にすることができる。

東京都の夜間人口の構成比は，10\%弱に過ぎな いが，構成比密度は 17.0 と断然トップになる。東 京への集中が激しい貸出残高などは，構成比その ものが $38.1 \%$ と飛び抜けて大きいが，構成比密度

でみると 2 位大阪の 24.7 の倍以上の 66.4 と比較に ならないような大きさに達している。

東京都の人口の構成比密度は 10 年間に, 夜間人 ロが，18.2から17.0へと下がったが，昼間人口も 20.8から20.2へと減少している。

2. 全体地域の集中指標

(i) 集中指数

集中指数は，O. D. ダンカンによって考案され た手法で5)，各部分地域ごとの面積の構成比と事 象の構成比の差を全地域にわたって加算すること によって，全体としての集中傾向を明らかにする 指標である。集中指数Cは次の式で算定される。

$$
\mathrm{C}=\left(\Sigma\left|\mathbf{x}_{\mathbf{i}}-\mathbf{a}_{\mathbf{i}}\right|\right) / 2
$$

$x_{i}$ : 部分地域 $\mathrm{i}$ の事象の構成比パーセント

$a_{i}$ : 部分地域 $\mathrm{i}$ の面積構成比パーセント

事象の構成比と面積の構成比が近ければ，差は 0 に近くなり, 差が小さい部分地域が多ければ, すなわち，広い地域には多く，狭い地域には少な く，おおむね均等に分布していれば，Cの值は小 さくなる。それに対して，東京や大阪のように狭 い地域に多くの人口が集中している場合, 両者の 構成比の差は大きくなり，そのように構成比の乘 離が大きい地域が多数あれば，全体としてCは大 きくなる。この場合，ある特定の地域における恶 離が大きいことによってCが大きくなっても，い くつかの地域における差の集積でCが大きくなっ ても区別はできない。

わが国において，1975年から1985年までの10年 間に, 夜間人口の集中指数が 39.7 から 40.5 と高ま り，昼間人口では40.0から40.7へ上昇し，それぞ れ集中が進んでいることがわかる。

(ii) ローレンツ曲線

構成比を大から小の順に加算した累積構成比を 面積と事象のそれぞれに対して求め，面積を横軸 にとり，事象を縦軸にとって，縦横同スケールで グラフを描く。おおむね均等に分布していて，両 者の累積構成比の差が僅かならば，グラフは勾配 45度の右上がりの直線に近い曲線となり，集中し ている場合は，弓形の曲線になる。この曲線は口 ーレンツ曲線 (Lorenz curve) と呼ばれ，もとも とは所得の不平等な状態をみるために考案された ものであるが，地域的な分布の不均一を知るため 
に応用したものである。図 1 に1985年の都道府 県別人口によるローレンツ曲線を示す。

(iii) 集中係数

集中係数は, ローレンッ曲線と対角線の間の 面積を測り，その大きさから数量的に事象の地 域的な偏在状況を知万うとするもので，ジニの 集中倸数と呼ばれている。

ジニの集中係数 $\mathrm{G}$ は, 次式で算出される。

$$
G=\left(\sum_{i=1}^{n} x_{i} \times a_{i+1}\right)-\left(\sum_{i=1}^{n} x_{i+1} \times a_{i}\right)
$$

$\mathrm{n}=$ 部分地域の数

$\mathrm{x}_{\mathrm{i}}$ : 部分地域の事象の榡積構成比パーセント

$a_{j}$ : 部分地域の面積構成比パーセント

ジニの集中係数は，ローレンッ曲線の図に示 す弓形の部分の面積の 2 倍で, その面積は, 斜 線の部分を $\mathrm{x}_{0}$ から $\mathrm{x}_{\mathrm{n}}$ まで（0\%から $100 \%$ まで） 集計した値である。

1975年と 1985 年の都道府県別人口の集中状況を ジニの集中係数から知るため計算した結果, 0.458 から0.461と僅かに上昇していることが明らかに なった。東京都の構成比そのものは多少低下して も, 茨城, 埼玉, 千葉など, いくつかの県で構成 比が高まっているので, 全体として集中の傾向が 進んでいることがわかる。

\section{IV. 集中総合指標の開発}

\section{1. 集中総合指標の検討}

集中についてこれまで用いられてきた指標は単 一の指標が主であった。人口と銀行数と所得とい うように, いくつかのデータを並列して示すこと はあっても，それぞれのデータが相互の関連なく ただ列挙されているだけというのが殆どである。 都市が様々な要素の複合によって形成されている ことから考えて, 単独の指標が有機的な関連を欠 いて羅列されているだけでは, 都市のいくつかの 側面を見ることにはなり，それはそれで意義があ るが，都市の実態を明確化する指標としては有効 性にそしい。

都市への集中を示寸ためには, 調査・研究の目 的に適したデータを選ぶべきことを前述したが， 都市の総合的な把握のためには, 総合的な集中指 標が必要である。しかしながらこれまでに, 適切

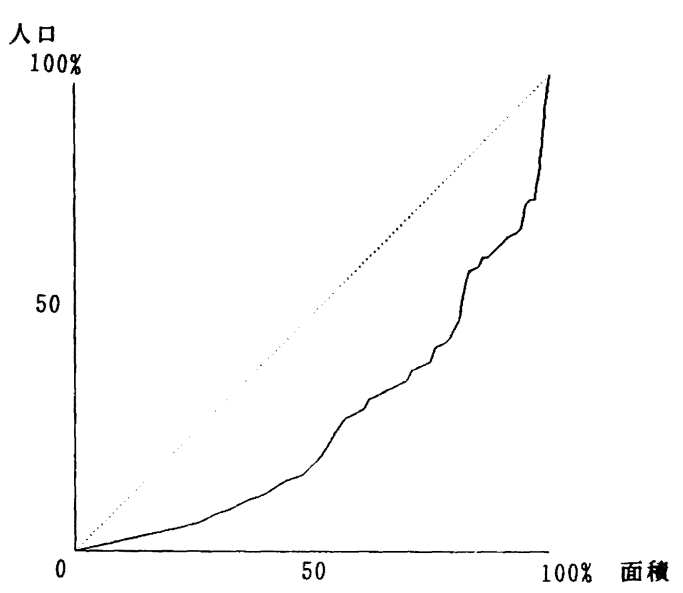

図 1 都道府県人ロローレンツ曲線（1985年）

な集中総合指標は見出されていない。研究者がそ れぞれの目的に従って, 最も良好と思われる方法 で指標を作成しているのが現状である。

東京都の立場からすれば, 都市に止まらず, 複 数のデータからなる都道府県単位の集中総合指標 の作成が必要である。一口に都道府県といって も，北海道のように大きな地域から香川県まで, 面積的な差が大きく，1000万を越す東京都から 島根県のように大きな市か区程度の人口の県ま で，人口規模の開きも大きい。一方, 現実に比較 検討が可能な統計は, 都道府県を単位にした集計 に限られている。必要性と可能性から考えて, 都 道府県を単位とすることが最も妥当である。

使用するデータの形式としては, 絶対数, 密度, 構成比などいくつか考えられる。絶対数は, 規模 に影響されるので，集中と直接関係がなく大きい 地域は多く表される。面積の大小による影響を取 り除くためには, 人口密度のような, 単位土地当 たりの数値が有効であるが，集積の規模が捨象さ れることと, 集中という相対的な関係が読取れな い点でやや不満足である。その意味から, 相対的 な関係を表す構成比が適当ということができる。 各都道府県の対全国シェアを主軸にした総合指標 が，今回の調査の目的に沿うものと考えられる。

2. 主成分分析手法の応用

なん種類かのデータを総合的に用いて分析を行 う場合, 通常, 多変量解析の手法を使用寸ること 
が多い。

多変量解析の一つである主成分分析は ${ }^{8)}$, 調查 対象のいくつかの側面を示寸複数のデー夕を適切 に集約して共通の要因を表す指標を作り, それを 尺度として分析を行うものである。例えば, 都道 府県を調査対象として，それぞれの地域の性格を 分析しょうとする場合, 都道府県別に年齢別人口 や工業出荷額, あるいは農地面積など, なん種類 かのデータが 分析の材料になる。主成分分析で は，まず，それらのデー夕を変量あるいは変数と 呼び，それぞれを無䭾にしないように，かつ，過 大に評価しないように, 統計学的な処理によって 適切なウエイトゔけをほどこして, 共通の要素を 測定する主成分と呼ぶ尺度を算出する。次に，そ の尺度で各都道府県を点検しながら，尺度のもつ 意味を考察し，その尺度が都道府県の共通要素と して，なにを表しているのか，才なわち，高齢化 とか工業化というように, 判断する。そして改め て, 各都道府県でそれがどの程度か評価する。

しかしながら, 複雑な側面をもつ多数の都市や 都道府県を一つの尺度のみで測ることは，困難な 場合が多い。現実には，第二, 第三の尺度を求め ながら，それぞれの尺度の意味ゔけを行い，その うえで総合的に評価する。それらを第二主成分, 第三主成分と呼び, 統計学的に定めた基準を満た すまで，以下第四，第五と算出して，意味ゔけと 評価を繰り返す。

主成分分析において, 主成分の状態, 寸なわち 新たに作る尺度の性格は, 上記の各変量との関連 の強弱を示す数值によって表す。主成分を算出す る計算を行うと数学的には固有ベクトルと呼ばれ る一組の数が得られ，それらの数がそれぞれの変 量と主成分の関係を表す。主成分と变量全体との 関連を意味する数值は, 数学的には固有值といわ れるものである。固有値が大きい主成分は, 全体 をよく代表していると考えられるので，ある一つ の主成分の固有值と全主成分の固有値の合計との 比率をもって寄与率と呼んでいる。

以上が，主成分分析の一般的な進めかたである が，ここでは，主成分分析の性格を利用して，集 中の度合いを表す尺度をつくり出そうとする。各 方面の様々なデータから共通の尺度を見出す代わ
りに，集中に関連するデータに限定して，そのな かでの様々なデータから共通の尺度をつくる。で きた尺度，いい換えれば，算出された主成分は， 集中の程度を測る基準になり, その主成分の值を 都道府県別に比較することによって, 特定の都道 府県の集中の状況を把握することができる。

既に, 都市への集中は工業化, 情報化に起因す ることが研究や経験によって, 定性的には, 明ら かにされている。人口, 工業, 商業, 情報産業, 金融など，大都市への集中が著しい機能に関する データを選択することによって, 集中を表す共通 尺度を導き出すことが可能になる。

データは, 表 1 に示すように, 1985年の定住人 口, 第 1 次, 2 次, 3 次別就業者数, 昼間人口, 事業所数, 従業者数, 総生産, 雇用所得, 預貯金 残高, 電子計算機台数, 情報サービス業売上高, 郵便引受け数, 大学・短大 - 高専学生数, 病床数, 可住地面積, 宅地面積, 鉄道 - 自動車旅客数, 1986 年の事業所数, 従業者数という18個の変量の都道 府県別の構成比を用いた。

計算の結果, 表 2 に示すとおり, 第一主成分す なわち，最初に抽出された尺度の寄与率は，79.8 \%と極めて大きく，これだけで，全体の状況のほ ぼ 8 割方を説明することができるとみてよい。第 二主成分の寄与率が $13.7 \%$ であから，この二つ だけでも累計で 9 割 5 分近く説明していることに なる。表 2 は, 固有值と固有べクトルを, 第一主 成分から第五主成分まで示している。第五主成分 までで，累積寄与率が $99.9 \%$ を越すため，それ以 上計算しても意味がない。

第一主成分の固有ベクトル，すなわち第一の尺 度と各変量との関連を示す数值をそれぞれみる と, 第一次産業の就業者数がマイナスになってい るのと可住地面積が 小さい值になっているだけ で，そのほかは，宅地面積が多少低いのを除い て，ほぼ同程度のプラスの值になっている。この ことは，それぞれの変量がいずれも第一主成分と 密接な関係にあることを意味している。使用した 変量は, 工業, 情報, 金融など, 大都市に集中し ている機能を示すものであり, それらと密接な関 係にあるこの第一主成分は，都市部への集中を意 味する尺度と考えることが可能である。 
そもそも，ここでは各々のデータを十分活用 し，それらに共通の要素を抽出するという主成分 分析の特質を利用し，集中に関倸が深いと思われ ている変量を意図的に選び，それを用いることに よって集中の状況を総合的に数値を示す尺度を作 り出そうとしたのである。第一主成分を算出して 固有值や固有ベクトルを点検した結果, 意図した とおりの尺度を求めえたことが確認された。

3. 集中総合指標による集中度の試算

このように, 主成分分析によって，集中を測定 する適切な尺度が得られたので，それを用いて各 都道府県の集中度の算定を試みた。通常, それら の計算は, 主成分分析計算として, 一連の過程の 中で行われ，調查対象毎の主成分スコアとして求 められる。

その結果は表 1 の右端の列に示寸とおりであ る。これによれば，東京都は，19.545 と圧倒的 な差で第 1 位にランクされる。2 位は大阪府で $8.989,3$ 位は神奈川県で $5.317,4$ 位は愛知県の 5.239 と続く。

これを1980年のデータに変えて，1980年の集中 度を計算し, 1985年の值と比べてみると, 東京都 や愛知県治ど変化がなく, 神奈川県が少し高く なったことがわかる。

\section{4. 集中総合指標の非負化}

適切なデータを用いて主成分分析を行うことに よって, 集中の尺度が得られたが, 前出の表を点 検していくと, 集中度がマイナスの值になる県が いくつか見られる。これは, 全データに共通の尺 度を作り出すといら主成分分析の性格から来るも ので, 平均的な状態から上位にあればプラスにな り，下位にあればマイナスになるのは当然であ る。しかし，マイナスの集中とは理解しにくい。 また, プラス19.55とマイナス1.81の集中度の差 を, 19.55- $(-2.58)=22.13$ と単純に求めてよい のか疑問が残る。

主成分得点を全体的にシフトアップすれば， 、 イナス值はなくなるが, その場合でも, 最高得点 の 22.13 と最低得点の 0 の意味付けが必要である。 距離尺度である主成分得点を比尺度に直すために は, なんらかの意味のある変換を行わなければな らない。
本研究では，下に示す方法で変換をおこなっ た。

その趣旨は, 主成分得点にある数 $\mathrm{c}$ を加えて非 負化した数 $\mathrm{y}_{\mathrm{i}}+\mathrm{c}$ が, 比尺度として意味をもつ ため, $\mathrm{y}_{\mathrm{i}}+\mathrm{c}$ と $\mathrm{y}_{\mathrm{j}}+\mathrm{c}$ の比が, 比尺度である元 の変量 $\mathrm{x}_{\mathbf{i}}$ と $\mathrm{x}_{\mathbf{j}}$ の比に近い関釈になるような $\mathrm{c}$ を見出すことである。

そのため，まず使用した変量のなかで第一主成 分と相関関係が高い変量, すなわち固有ベクトル の大きい変量を選び出す7)。次に, 全調査対象か ら二組の変量と主成分得点を取り出して, それぞ れの主成分得点にマイナスをなくすための任意の 正数を加えた值どうしの比と, それぞれの前述の 変量の比を求め, 両者の差を出し， 2 乗する。同 様な計算を全調查対象全ての組み合わせについて 行い, それらの 2 乗和が最小になった時の任意の 正数の値を最適な加算定数として定める。

これを式で表すと，選び出した変量を $\mathrm{x}_{\mathbf{i}}, \mathrm{x}_{\mathbf{j}}$ と し，それに対応する主成分得点を $y_{i}, y_{j}$ とし, 加 える数を $\mathrm{c}$ として,

$$
\mathrm{s}=\sum_{\mathrm{i}} \sum_{\mathrm{j}}\left(\mathrm{x}_{\mathrm{j}} / \mathrm{x}_{\mathrm{i}}-\left(\mathrm{y}_{\mathrm{j}}+\mathrm{c}\right) /\left(\mathrm{y}_{\mathrm{i}}+\mathrm{c}\right)\right)^{2}
$$

を最小にする $\mathrm{c}$ を求めることになる。すなわち， $\mathrm{s}$ を $\mathrm{c}$ て偏微分して0とおくと, その時の $\mathrm{c} か ゙$ 求 める加算定数である。実際には, 次の式

$$
\begin{gathered}
\sum_{i} \sum_{j} \frac{\left(y_{i}-y_{j}\right)\left\{c\left(x_{i}-x_{j}\right)+\left(x_{i} \cdot y_{j}-x_{j} \cdot y_{i}\right)\right\}}{x_{i}\left(c+y_{i}\right)^{3}} \\
\quad=0
\end{gathered}
$$

に, c としてy の最小值の絶対值より大きい正数 を入れて, 式の值を求め, $\mathrm{c}$ の值を増しながら式 の值が 0 になるまで計算を繰り返し，そのときの c を加算定数とする8。

この方法は，上笹（1987）が考案した方法を， $\mathrm{c}$ を実際に求める段階に偏微分を導入して，パソ コンで算出するように改めたものである。これに よって, 距離尺度である主成分得点が比尺度に転 換され，マイナスの数値がなくなると同時に, 倍 率として比較可能になる。

この方法を用いるため, 第一主成分と相関の高 い変量として, 固有ベクトル值が 0.26 を超す, 3 次産業就業者, 昼間人口, 事業所数, 従業者, 総 生産, 鉄道自動車旅客数を選んだ。これらの変量 と第一主成分の主成分得点から加算する定数が 
表 1 都道府県別構成比

\begin{tabular}{|c|c|c|c|c|c|c|c|c|c|c|}
\hline 都道府 & & 人 口 & $\begin{array}{l}1 \text { 次 } \\
\text { 就業者 }\end{array}$ & $\begin{array}{cc}2 & \text { 次 } \\
\text { 就業者 }\end{array}$ & $\begin{array}{c}3 \text { 次 } \\
\text { 就業者 }\end{array}$ & $\begin{array}{ll}\text { 昼 } & \text { 間 } \\
\text { 人 } & \text { 口 } \\
\end{array}$ & $\begin{array}{c}\text { 事業所 } \\
1986\end{array}$ & $\begin{array}{c}\text { 従業者 } \\
1986 \\
\end{array}$ & 総生産 & $\begin{array}{ll}\text { 雇 } & \text { 用 } \\
\text { 所 } & \text { 得 } \\
\end{array}$ \\
\hline 全 & 国 & 100.0 & 100.0 & 100.0 & 100.0 & 100.0 & 100.0 & 100.0 & 100.0 & 100.0 \\
\hline 北 海 i & 道 & 4.7 & 6.2 & 3.2 & 5.0 & 4.7 & 4.3 & 4.3 & 4.0 & 4.4 \\
\hline 青 & 森 & 1.3 & 3.1 & 0.8 & 1.2 & 1.3 & 1.2 & 1.0 & 0.9 & 0.8 \\
\hline 岩 & 手 & 1.2 & 3.4 & 1.0 & 1.1 & 1.2 & 1.1 & 1.0 & 0.8 & 0.9 \\
\hline 宮 & 城 & 1.8 & 2.7 & 1.4 & 1.8 & 1.8 & 1.7 & 1.7 & 1.6 & 1.6 \\
\hline 秋 & 田 & 1.0 & 2.4 & 0.9 & 0.9 & 1.0 & 1.0 & 0.9 & 0.8 & 0.7 \\
\hline 山 & 形 & 1.0 & 2.5 & 1.1 & 0.9 & 1.0 & 1.1 & 1.0 & 0.8 & 0.8 \\
\hline 福 & 島 & 1.7 & 3.7 & 1.8 & 1.4 & 1.7 & 1.7 & 1.6 & 1.5 & 1.5 \\
\hline 茨 & 城 & 2.3 & 4.1 & 2.4 & 1.9 & 2.2 & 2.0 & 2.0 & 2.1 & 2.0 \\
\hline 杤 & 木 & 1.5 & 2.4 & 1.9 & 1.3 & 1.5 & 1.6 & 1.5 & 1.6 & 1.5 \\
\hline 群 & 馬 & 1.6 & 2.3 & 2.0 & 1.4 & 1.6 & 1.7 & 1.6 & 1.5 & 1.4 \\
\hline 埼 & 玉 & 4.8 & 2.5 & 5.5 & 4.7 & 4.2 & 3.8 & 3.8 & 3.5 & 5.0 \\
\hline$千$ & 葉 & 4.3 & 3.6 & 3.7 & 4.5 & 3.7 & 3.0 & 3.1 & 3.4 & 4.7 \\
\hline 東 & 京 & 9.8 & 0.7 & 9.2 & 12.3 & 11.6 & 11.9 & 14.7 & 17.2 & 13.6 \\
\hline 神 奈 & 川 & 6.1 & 1.1 & 6.8 & 6.4 & 5.6 & 4.6 & 5.5 & 5.9 & 7.7 \\
\hline 新 & 潟 & 2.0 & 3.2 & 2.3 & 1.9 & 2.0 & 2.3 & 2.1 & 1.8 & 1.9 \\
\hline 富 & 山 & 0.9 & 1.1 & 1.2 & 0.9 & 0.9 & 1.0 & 1.0 & 0.9 & 0.9 \\
\hline 石 & 川 & 1.0 & 1.0 & 1.0 & 1.0 & 1.0 & 1.2 & 1.0 & 0.9 & 0.9 \\
\hline 福 & 井 & 0.7 & 0.7 & 0.9 & 0.7 & 0.7 & 0.9 & 0.7 & 0.6 & 0.6 \\
\hline 山 & 梨 & 0.7 & 1.1 & 0.7 & 0.6 & 0.7 & 0.8 & 0.7 & 0.6 & 0.6 \\
\hline 長 & 野 & 1.8 & 3.6 & 2.2 & 1.6 & 1.8 & 1.9 & 1.8 & 1.6 & 1.5 \\
\hline 岐 & 阜 & 1.7 & 1.3 & 2.3 & 1.5 & 1.6 & 1.9 & 1.6 & 1.5 & 1.5 \\
\hline 静 & 岡 & 3.0 & 3.0 & 3.7 & 2.8 & 3.0 & 3.2 & 3.2 & 3.0 & 2.9 \\
\hline 要 & 知 & 5.3 & 3.0 & 7.0 & 5.2 & 5.4 & 5.6 & 6.0 & 6.7 & 5.7 \\
\hline 三 & 重 & 1.4 & 1.6 & 1.7 & 1.3 & 1.4 & 1.4 & 1.4 & 1.3 & 1.3 \\
\hline 滋 & 賀 & $1.0 、$ & 0.9 & 1.2 & 0.8 & 0.9 & 0.9 & 0.9 & 1.0 & 0.9 \\
\hline 京 & 都 & 2.1 & 1.1 & 2.1 & 2.2 & 2.2 & 2.5 & 2.2 & 2.0 & 2.1 \\
\hline 大 & 阪 & 7.2 & 0.6 & 7.6 & 7.5 & 7.5 & 8.0 & 8.5 & 8.7 & 8.0 \\
\hline 兵 & 庫 & 4.4 & 2.0 & 4.4 & 4.3 & 4.2 & 4.1 & 4.0 & 4.1 & 4.4 \\
\hline 奈 & 良 & 1.1 & 0.6 & 1.0 & 1.0 & 0.9 & 0.8 & 0.7 & 0.7 & 0.9 \\
\hline 和 歌 & 山 & 0.9 & 1.5 & 0.7 & 0.8 & 0.9 & 1.0 & 0.8 & 0.7 & 0.7 \\
\hline 鳥 & 取 & 0.5 & 1.1 & 0.5 & 0.5 & 0.5 & 0.5 & 0.5 & 0.4 & 0.4 \\
\hline 島 & 根 & 0.7 & 1.4 & 0.7 & 0.6 & 0.7 & 0.7 & 0.6 & 0.5 & 0.6 \\
\hline 岡 & 山 & 1.6 & 2.1 & 1.8 & 1.4 & 1.6 & 1.5 & 1.5 & 1.6 & 1.5 \\
\hline 広 & 島 & 2.3 & 2.0 & 2.4 & 2.3 & 2.3 & 2.3 & 2.3 & 2.3 & 2.3 \\
\hline 山 & 口 & 1.3 & 1.9 & 1.2 & 1.3 & 1.3 & 1.3 & 1.2 & 1.2 & 1.2 \\
\hline 徳 & 島 & 0.7 & 1.3 & 0.6 & 0.6 & $0.7^{\circ}$ & 0.7 & 0.6 & 0.5 & 0.5 \\
\hline 香 & 川 & 0.8 & 1.3 & 0.8 & 0.8 & 0.8 & 0.9 & 0.8 & 0.7 & 0.7 \\
\hline 票 & 媛 & 1.3 & 2.2 & 1.1 & 1.1 & 1.3 & 1.3 & 1.1 & 1.0 & 0.9 \\
\hline 高 & 知 & 0.7 & 1.4 & 0.5 & 0.7 & 0.7 & 0.8 & 0.6 & 0.5 & 0.5 \\
\hline 福 & 岡 & 3.9 & 2.6 & 3.0 & 4.1 & 3.9 & 3.8 & 3.7 & 3.7 & 3.6 \\
\hline 佐 & 賀 & 0.7 & 1.5 & 0.6 & 0.7 & 0.7 & 0.7 & 0.6 & 0.6 & 0.6 \\
\hline 長 & 崎 & 1.3 & 2.2 & 0.9 & 1.2 & 1.3 & 1.2 & 1.1 & 0.9 & 1.0 \\
\hline 熊 & 本 & 1.5 & 3.5 & 1.1 & 1.4 & 1.5 & 1.4 & 1.2 & 1.2 & 1.3 \\
\hline 大 & 分 & 1.0 & 1.9 & 0.7 & 1.0 & 1.0 & 1.0 & 0.9 & 0.8 & 0.8 \\
\hline 宮 & 崎 & 1.0 & 2.2 & 0.7 & 0.9 & 1.0 & 1.0 & 0.8 & 0.7 & 0.7 \\
\hline 鹿＼cjkstart児 & 島 & 1.5 & 3.6 & 1.1 & 1.4 & 1.5 & 1.5 & 1.2 & 1.1 & 1.1 \\
\hline 沖 & 繩 & 1.0 & 0.9 & 0.5 & 1.0 & 1.0 & 1.0 & 0.8 & 0.6 & 0.6 \\
\hline
\end{tabular}


単位：\%

\begin{tabular}{|c|c|c|c|c|c|c|c|c|c|}
\hline $\begin{array}{ll}\text { 預 } & \text { 貯 } \\
\text { 残 } & \text { 高 } \\
\end{array}$ & $\begin{array}{ll}\text { 電 } & \text { 算 } \\
\text { 台 } & \text { 数 } \\
\end{array}$ & $\begin{array}{l}\text { 情報サ } \\
\text { 売 上 } \\
\end{array}$ & $\begin{array}{ll}\text { 船 } & \text { 便 } \\
\text { 引 } & \text { 受 } \\
\end{array}$ & $\begin{array}{l}\text { 大短専 } \\
\text { 各 校 }\end{array}$ & 病床数 & $\begin{array}{l}\text { 可住地 } \\
\text { 面 積 }\end{array}$ & $\begin{array}{ll}\text { 宅 地 } \\
\text { 面 積 }\end{array}$ & $\begin{array}{l}\text { 鉄 自 } \\
\text { 旅客数 }\end{array}$ & 総合指標 \\
\hline 100.0 & 100.0 & 100.0 & 100.0 & 100.0 & 100.0 & 100.0 & 100.0 & 100.0 & \\
\hline 2.9 & 3.5 & 2.2 & 3.8 & 3.5 & 6.3 & 18.4 & 6.3 & 4.5 & 3.919 \\
\hline 0.7 & 0.6 & 0.1 & 0.7 & 0.6 & 1.4 & 2.5 & 1.7 & 0.9 & -1.599 \\
\hline 0.6 & 0.5 & 0.2 & 0.7 & 0.5 & 1.4 & 3.0 & 1.8 & 0.8 & -1.624 \\
\hline 1.1 & 1.6 & 0.9 & 1.6 & 2.0 & 1.5 & 2.6 & 2.3 & 1.5 & -0.674 \\
\hline 0.6 & 0.9 & 0.2 & 0.6 & 0.4 & 1.2 & 2.6 & 1.5 & 0.7 & -1.828 \\
\hline 0.5 & 1.5 & 0.1 & 0.6 & 0.4 & 0.8 & 2.4 & 1.5 & 0.7 & -1.810 \\
\hline 0.9 & 0.7 & 0.4 & 1.0 & 0.8 & 2.0 & 3.4 & 2.4 & 1.3 & -0.821 \\
\hline 1.7 & 0.9 & 0.9 & 1.1 & 1.1 & 2.0 & 3.2 & 3.8 & 1.8 & -0.039 \\
\hline 1.2 & 0.8 & 0.4 & 0.8 & 0.7 & 1.4 & 2.4 & 2.4 & 1.1 & -0.993 \\
\hline 1.2 & 0.9 & 0.6 & 0.9 & 0.9 & 1.5 & 1.9 & 2.3 & 1.1 & -0.921 \\
\hline 3.6 & 2.3 & 0.7 & 2.5 & 2.8 & 3.2 & 2.1 & 4.1 & 4.0 & 2.809 \\
\hline 2.8 & 1.5 & 0.7 & 2.4 & 2.4 & 2.9 & 2.8 & 4.2 & 4.2 & 2.110 \\
\hline 27.8 & 32.6 & 53.9 & 31.3 & 28.8 & 8.8 & 1.1 & 4.0 & 19.6 & 19.545 \\
\hline 4.8 & 3.4 & 8.8 & 4.5 & 5.2 & 4.2 & 1.2 & 3.9 & 8.0 & 5.317 \\
\hline 1.3 & 1.3 & 1.0 & 1.1 & 0.9 & 1.8 & 3.8 & 2.7 & 1.4 & -0.319 \\
\hline 0.8 & 0.7 & 0.5 & 0.6 & 0.6 & 1.2 & 1.5 & 1.4 & 0.7 & -1.784 \\
\hline 0.8 & 3.0 & 0.4 & 0.8 & 0.9 & 1.4 & 1.2 & 1.1 & 0.8 & -1.619 \\
\hline 0.6 & 0.5 & 0.3 & 0.4 & 0.5 & 0.8 & 0.9 & 0.9 & 0.5 & -2.192 \\
\hline 0.5 & 0.5 & 0.1 & 0.5 & 0.5 & 0.7 & 0.8 & 0.9 & 0.5 & -2.262 \\
\hline 1.3 & 1.2 & 0.6 & 1.4 & 0.8 & 1.6 & 2.7 & 2.5 & 1.3 & -0.647 \\
\hline 1.3 & 0.9 & 0.3 & 1.0 & 1.1 & 1.4 & 1.7 & 2.1 & 1.4 & -0.830 \\
\hline 2.3 & 2.0 & 0.5 & 2.0 & 1.3 & 2.1 & 2.2 & 3.4 & 2.5 & 1.004 \\
\hline 5.3 & 5.4 & 3.9 & 4.8 & 6.9 & 4.5 & 2.4 & 5.0 & 5.7 & 5.239 \\
\hline 1.1 & 0.6 & 0.2 & 0.8 & 0.9 & 1.4 & 1.6 & 1.9 & 1.2 & -1.209 \\
\hline 0.7 & 0.4 & 0.3 & 0.6 & 0.3 & 0.8 & 1.1 & 1.3 & 0.8 & -1.908 \\
\hline 2.2 & 1.7 & 0.7 & 2.4 & 4.9 & 2.4 & 1.0 & 1.4 & 2.3 & 0.103 \\
\hline 10.7 & 13.9 & 13.9 & 10.7 & 9.2 & 7.2 & 1.1 & 3.5 & 9.2 & 8.989 \\
\hline 3.6 & 2.2 & 1.1 & 3.2 & 4.1 & 3.8 & 2.2 & 3.5 & 4.3 & 2.777 \\
\hline 1.0 & 0.3 & 0.0 & 0.7 & 0.9 & 0.8 & 0.7 & 0.9 & 1.0 & -1.958 \\
\hline 0.7 & 0.4 & 0.0 & 0.6 & 0.6 & 1.0 & 0.9 & 0.9 & 0.6 & -2.066 \\
\hline 0.4 & 0.2 & 0.1 & 0.3 & 0.3 & 0.5 & 0.7 & 0.6 & 0.3 & -2.577 \\
\hline 0.4 & 0.2 & 0.1 & 0.4 & 0.2 & 0.7 & 1.0 & 0.8 & 0.4 & -2.357 \\
\hline 1.2 & 0.9 & 0.7 & 1.7 & 1.1 & 2.1 & 1.8 & 2.1 & 1.1 & -0.849 \\
\hline 1.9 & 2.5 & 1.0 & 2.3 & 2.0 & 2.3 & 1.9 & 2.1 & 1.8 & 0.137 \\
\hline 1.0 & 0.6 & 0.3 & 0.9 & 0.9 & 1.7 & 1.4 & 1.7 & 0.9 & -1.359 \\
\hline 0.6 & 0.3 & 0.1 & 0.4 & 0.5 & 1.1 & 0.8 & 0.8 & 0.4 & -2.292 \\
\hline 0.8 & 0.9 & 0.3 & 0.6 & 0.5 & 1.2 & 0.8 & 1.0 & 0.5 & -2.027 \\
\hline 0.9 & 0.6 & 0.3 & 0.9 & 0.7 & 1.5 & 1.4 & 1.4 & 0.7 & -1.558 \\
\hline 0.4 & 0.3 & 0.1 & 0.4 & 0.3 & 1.4 & 1.0 & 0.6 & 0.4 & -2.286 \\
\hline 3.1 & 3.4 & 1.7 & 3.6 & 4.6 & 5.3 & 2.3 & 3.9 & 3.6 & 2.600 \\
\hline 0.4 & 0.3 & 0.1 & 0.4 & 0.3 & 1.0 & 1.1 & 0.8 & 0.5 & -2.286 \\
\hline 0.9 & 0.6 & 0.1 & 0.7 & 0.6 & 1.8 & 1.4 & 1.2 & 0.9 & -1.573 \\
\hline 0.9 & 0.5 & 0.2 & 0.9 & 1.1 & 2.3 & 2.3 & 1.8 & 1.0 & -1.170 \\
\hline 0.6 & 0.5 & 0.2 & 0.6 & 0.6 & 1.2 & 1.5 & 1.2 & 0.7 & -1.896 \\
\hline 0.5 & 0.4 & 0.2 & 0.5 & 0.3 & 1.3 & 1.5 & 1.4 & 0.6 & -1.938 \\
\hline 0.8 & 0.6 & 0.2 & 0.9 & 0.8 & 2.1 & 2.7 & 2.1 & 1.0 & -1.186 \\
\hline 0.5 & 0.5 & 0.1 & 0.4 & 0.7 & 0.9 & 0.9 & 0.8 & 0.8 & -2.081 \\
\hline
\end{tabular}


表 2 主成分分析 固有值, 固有ベクトル（1985年）

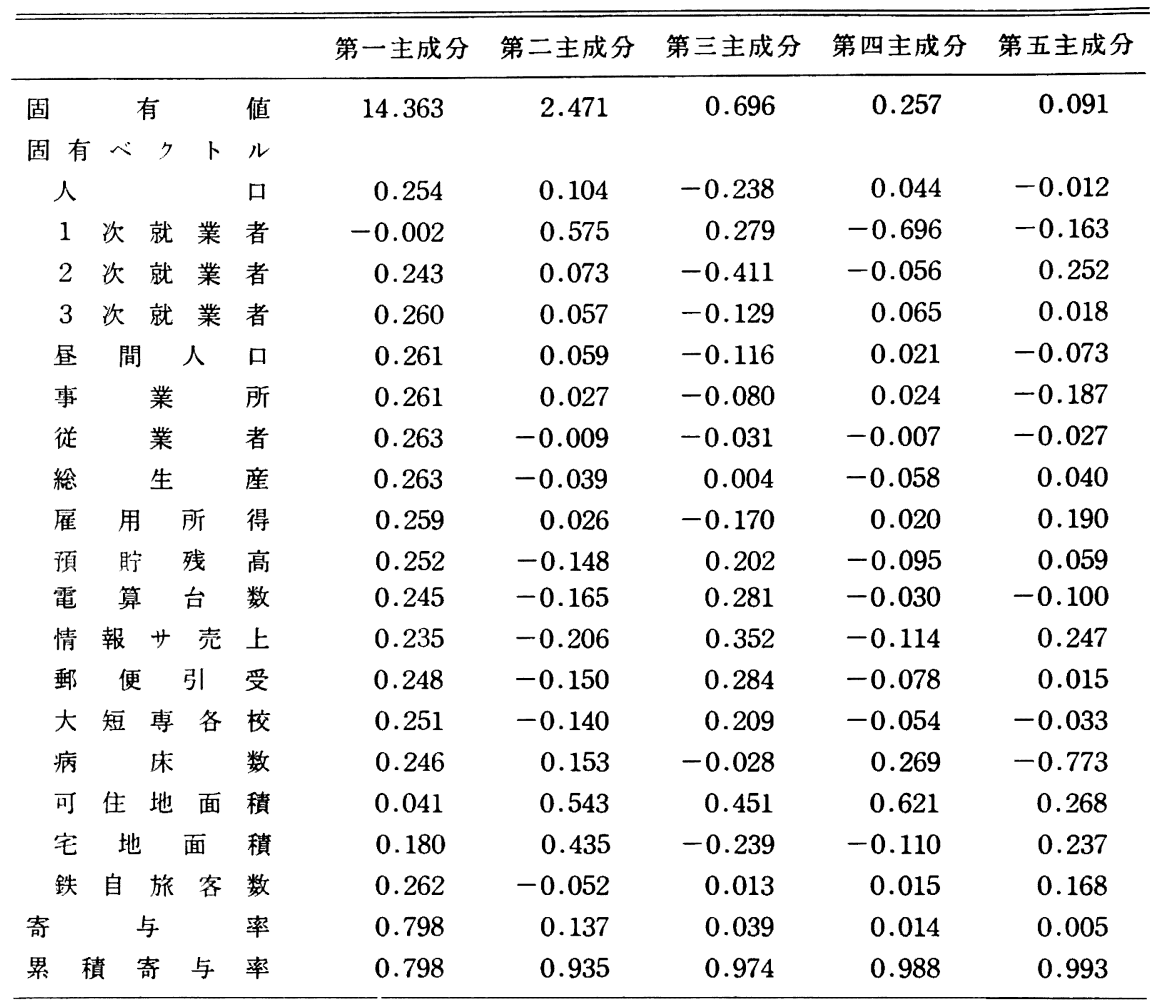

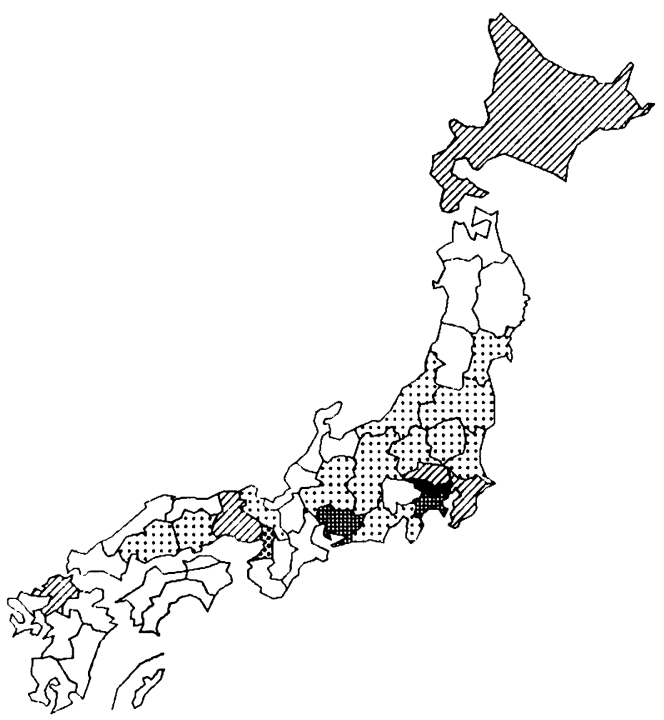

図 2 総合指標による集中度分布（1985年） 
地域的集中総合指標からみた東京一の集中

表 3 集中総合指標（尺度変換済）

\begin{tabular}{|c|c|c|c|}
\hline 都道府県 & 1985年 & 1980年 & $\begin{array}{c}\text { 1985年 } \\
\text { 一般データ }\end{array}$ \\
\hline 北 海 道 & 7.128 & 7.527 & 7.523 \\
\hline 青＼cjkstart森 & 1.610 & 1.646 & 1.707 \\
\hline 岩 手 & 1.585 & 1.604 & 1.695 \\
\hline 宮城 & 2.535 & 2.555 & 2.700 \\
\hline 秋 田 & 1.381 & 1.435 & 1.441 \\
\hline 山 形 & 1.399 & 1.423 & 1.455 \\
\hline 島 & 2.388 & 2.396 & 2.580 \\
\hline 城 & 3.170 & 3.009 & 3.538 \\
\hline 杤 木 & 2.216 & 2.195 & 2.464 \\
\hline 馬 & 2.288 & 2.226 & 2.542 \\
\hline 玉 & 6.018 & 5.684 & 6.495 \\
\hline 千 葉 & 5.319 & 5.023 & 5.795 \\
\hline 東＼cjkstart京 & 22.754 & 22.906 & 21.823 \\
\hline 神 奈 川 & 8.526 & 8.169 & 9.149 \\
\hline 新＼cjkstart潟 & 2.890 & 2.982 & 3.060 \\
\hline 山 & 1.425 & 1.457 & 1.521 \\
\hline 川 & 1.590 & 1.496 & 1.530 \\
\hline 井 & 1.017 & 1.034 & 1.057 \\
\hline 梨 & 0.947 & 0.894 & 0.999 \\
\hline 野 & 2.562 & 2.595 & 2.794 \\
\hline 阜 & 2.379 & 2.407 & 2.545 \\
\hline 岡 & 4.213 & 4.212 & 4.708 \\
\hline 知 & 8.448 & 8.573 & 9.523 \\
\hline 重 & 2.000 & 2.021 & 2.227 \\
\hline 賀 & 1.301 & 1.308 & 1.442 \\
\hline 都 & 3.312 & 3.418 & 3.458 \\
\hline 阪 & 12.198 & 12.368 & 12.602 \\
\hline 庫 & 5.986 & 6.164 & 6.479 \\
\hline 奈 良 & 1.251 & 1.221 & 1.312 \\
\hline 和 歌 山 & 1.143 & 1.220 & 1.239 \\
\hline 鳥 取 & 0.632 & 0.661 & 0.661 \\
\hline 根 & 0.852 & 0.872 & 0.888 \\
\hline 山 & 2.360 & 2.388 & 2.598 \\
\hline 島 & 3.346 & 3.477 . & 3.573 \\
\hline 口 & 1.850 & 1.905 & 2.038 \\
\hline 島 & 0.917 & 0.936 & 0.957 \\
\hline 川 & 1.182 & 1.282 & 1.249 \\
\hline 媛 & 1.651 & 1.719 & 1.788 \\
\hline 知 & 0.923 & 0.992 & 0.955 \\
\hline 岡 & 5.809 & 5.859 & 6.089 \\
\hline 賀 & 0.923 & 0.929 & 0.967 \\
\hline 崎 & 1.636 & 1.659 & 1.721 \\
\hline 本 & 2.039 & 2.007 & 2.179 \\
\hline 分 & 1.313 & 1.359 & 1.406 \\
\hline 宮＼cjkstart崎 & 1.271 & 1.272 & 1.340 \\
\hline 鹿 児 島 & 2.023 & 1.988 & 2.149 \\
\hline 沖繩 & 1.128 & 1.021 & 1.142 \\
\hline
\end{tabular}


3.209 と算出された。この值を各都道府県の 第一 主成分得点に加えて非負化と比尺度化を行った結 果を第 3 表に示す。そのうち，1985年について， 図 2 に分布を表した。

同様に，1980年のデータについても加算する定 数を計算し，3.223 と求められた。1980年の場合 は，固有ベクトル值がほぼ 0.26 以上の変量を選 び，上記1985年の変量に雇用所得を加えたものと した。

5. 集中総合指標の合理性

集中総合指標は，集中の状況を浮彫りにするた め作成したもので，特に，集中に関連が深いと考 えられている变量を 意図的に選んで使用してい る。しかし，一般に主成分分析を地域の分析に用 いる場合，地域の状況に関する様々な变量を無差 別的に使用する。現在は都市化の時代ともいわれ ており，意図的に変量を選ばず都道府県を単位地 域として主成分分析を行えば，なん番目かに都市 化，すなわち都市部への集中を表す主成分が出現 することが推測される。都市集中を意味する主成 分が抽出されれば，それが集中の指標であると考 えることができる9

前記の 18 変量のうち，電子計算機台数と情報 サービス業売上を削除し，その代わりに，農林水 産業生産額, 製造品出荷額, 卸小売販売額を加え て，主成分分析を試みた。その結果，第一主成分 が，75\%の寄与率で集中を表す主成分と考えら れ，主成分得点の分布状況は，前記の集中総合指 標と似かよった傾向にあることが確かめられた。 表 3 に，非負化した值を示す。

以上の検討から，変量を適切に選んだ場合，主 成分得点を集中を表す良好な総合的指標として用 いうることの合理性が明らかになった。

6. 集中状況の比較

東京と大阪を単純に比較すると，東京都は，大 阪府に対して，人口 1.4 倍, 従業者数 1.7 倍, 総生 産 2 倍, 預貯金残高 2.6 倍などということができ る。一方, 可住地面積や宅地面積では殆ど差がな い。工業製品の出荷額は, 逆に, 大阪府が東京都 の1.2倍になっている。

東京の 集中が 殊更に述べられている傾向があ り，書籍の 発行所は 東京都に 全国の 8 割が 集中
し，大阪府の16.3倍に及んでいること，最近東京 都で急増した外国証券会社数は大阪府の36倍に達 した，というような数字によって，東京だけがガ リバー型に突出しているようなイメージがつくら れている。

1985年の非負化後の集中総合指標で比べると， 東京都が22.754で，大阪府の12.198の1.87倍にな っている。

集中総合指標は, 多数の変量から合理的に算出 した值である。これによると，東京都と大阪府の 集中状況は，お拈よそ 2 対 1 である。おおまかに いって，東京都は大阪府の 2 倍の機能が集中して いるのである。

同様に，愛知県は，8.448，神奈川県は，8.526 であるから，東京都は，愛知県と神奈川県の 3 倍 弱となっている。

総合指標の格差がどのような意味を持つか，そ れは, 今後の研究課題である。

\section{v. 研究課題としての東京への集中の特性}

これまでに，東京への集中の強さを総合的に表 す方法について論じてきた。しかし，集中の問題 の解明のためには，さらに進んで，東京への集中 の特性を明らかにすることが要請されている。

東京へ集中している機能，その程度，集中した 人や企業などの地域的分布，集中による環境の変 化，あるいは，他地域への影響等々，明らかにさ れなければならない課題がいくつかある。

筆者らは，目下，東京都庁に扔いて，東京への 諸機能の集中に伴う問題に対処するための調査研 究を実施中である。東京への 集中の特性につい て，機会が与えられれば，稿を改めて述べること に致したい。

\section{注}

1) 西岡 (1976, p 28) は, フーバーが「同 業種諸経営の地域的集中」等を集皘として いることを紹介している。集積経済につい ては，川嶋辰彦 (1977)，高阪宏行 (1984) などで論じられている。本研究では，集積 を常䝑的に促えた。

2）都市化について述べたものとして，地理学 では，木内他（1964），青木他（1979）な ど，経済学では，HARSCH (1973), 宮尾 
（1985）など, 社会学では, 倉沢（1968）, CASTELLS（1977）などを挙げることがで きる。

3）移動について, 地理学では, -WooD(1983) など，経済学では，信国（1974）などがあ る。

4）田辺編（1982）などがある。

5）大友（1982， p 36）による。

6）主成分分析を含む多変量解析について，多 くの出版物が刊行されているほか，コンピ ュータのプログラムも用意されている。

7）固有ベクトルが大きい変量が主成分と相関 関係が高いことについては，杉山(1983， p 35）などに述べられている。

8) $\mathrm{s}=\sum_{\mathrm{i}} \sum_{\mathrm{j}}\left(\mathrm{x}_{\mathrm{j}} / \mathrm{x}_{\mathrm{i}}-\left(\mathrm{y}_{\mathrm{j}}+\mathrm{c}\right) /\left(\mathrm{y}_{\mathrm{i}}+\mathrm{c}\right)\right)^{2}$

をcで偏微分して，展開し，整理すると $\sum \sum_{i} \frac{\left(y_{i}-y_{j}\right)\left\{c\left(x_{i}-x_{j}\right)+\left(x_{i} \cdot y_{j}-x_{j} \cdot y_{i}\right)\right\}}{x_{i}\left(c+y_{i}\right)^{3}}$ $=0$

がえられるが,この式を解いてc 求める ことは難しいので, $\mathrm{c}$ の値を次々に変えて この式に代入し，式の値が 0 になるまでコ ンピュータで収束計算を行う。c+yi をつ ねにプラスにする最小の $\mathrm{c}$ から始め, 式の 值を計算し，0にならなければ，順次 $\mathrm{c}$ を 大きくして式の值を計算し直し，0に近く なるまで計算を繰り返す。

9）神頭（1989）は, 愛知県の市町村の都市化 度を主成分分析で求めている。

\section{文献}

青木栄一・白坂 蕃・永野征男・福原正弘編 著（1979）: 現代日本の都市化. 古今書院, 376p.

HARSCH, W. Z. (1973): Urban Economic Analysis. McGraw-Hill Inc., New York. 喜多 登監訳 (1979): 都市化の経
済学、マグロウヒル好学社, 581p.

上笹 恒 (1987)：筑波研究学園都市におけ る住民意識変容の時空間的モデル化の試み. 社会心理学研究, 3, 48-56.

CAstells, M. (1977): La question urbaine. Francois Maspero, Paris. 山田 操 訳 (1984): 都市問題. 恒星社厚生閣，463 p.

川嶋辰彦（1977）：企業の立地と集積経済. 岡野行秀編 交通の経済学. 有斐閣, 146157.

木内信蔵・山鹿誠次・清水馨八郎・稲永幸男 編 (1964): 日本の都市化. 古今書院, 187 p.

神頭広好 (1989): 要知県地域の構造分析. 愛知大学中部地方産業研究所, 131p.

高阪宏行 (1984) : 地域経済分析. 高文堂, 232p.

倉沢 進 (1968)：日本の都市社会. 福村出 版, 269p.

宮尾尊弘（1985）：現代都市経済学。日本評 論社, $233 \mathrm{p}$.

西岡久雄 (1976): 経済地理分析. 大明堂, $322 \mathrm{p}$.

信国真载 (1974)：人口の地域間移動. 福地 崇生編 地域経済学. 有斐閣, 33-54.

大友 篤 (1982): 地城分析入門. 東洋経済 新報社, $261 \mathrm{p}$.

杉山高一 (1983): 多変量デー夕解析入門. 朝 倉書店, 172p.

田辺健一 (1982): 日本の都市システム. 古 今書院, $484 \mathrm{p}$.

Wood, R. (1979) : Population Analysis in Geography. Longman Inc., New York. 河邉 宏 - 小笠原節夫 - 高橋真一訳 (1983)：地域人口分析法. 古今書院, 377p. (1989年 8 月 16 日受付，1989年11月20日受理) 